\title{
Sandia National Laboratories 1979 Environmental Monitoring Report
}

\author{
Theodore N. Simmons
}

Propered by Sandta Laboratoriess Albuquerque, New Mexico 87185 and Livermore, California 94550 for the United States Department of Energy under Contract DE-AC0476DP00789

Printed Aprif 1980 
Issued by Sandia Laboratories, operated for the United States Department of Energy by Sandia Corporation.

\section{NOTICE}

This report was prepared as an account of work sponsored by the United States Government. Neither the United States nor the Department of Energy, nor any of their employees, nor any of their contractors, subcontractors, or their employees, makes any warranty, express or implied, or assumes any legal liability or responsibility for the accuracy, completeness or usefulness of any information, apparatus, product or process disclosed, or represents that its use would not infringe privately owned rights.

Printed in the United States of America

Available from

National Technical Information Service

U. S. Department of Commerce

5285 Port Roval Road

Springfield, VA 22161

Price: Printed Copy $\$ 4.50$; Microfiche $\$ 3.00$ 
SAND 80-0342

Un 1 imited Release

Printed April 1980
Distribution

Category UC-20e

SANDIA NATIONAL LABORATORIES 1979

ENVIRONMENTAL MONITOR ING REPORT

Theodore N. Simmons

Health Physics Division 3312

Sandia National Laboratories

Albuquerque, NM 87185

\begin{abstract}
Sandia National Laboratories in Albuquerque is located south of the city on two broad mesas. The local climate is arid continental. Radionuclides are released from five technical areas from the Laboratories' research activities. Sandia's environmental monitoring program searches for cesium-137, tritium, uranium, al pha emitters, and beta emitters in water, soil, air, and vegetation. No activity was found in public areas in excess of local background in 1979. The Albuquerque population receives only 0.076 person-rem (estimated) from airborne radioactive releases. While national security research is the laboratories' major responsibility, energy research is a major area of activity. Both these research areas cause radioactive releases.
\end{abstract}


Sandia Laboratories (Albuquerque, New Mexico) 7

Location $\quad 7$

Climate 9

Sandia's Technical Areas 11

Monitoring for Radioactive Material $\quad 12$

Sampling Sites $\quad 13$

Fallout Collectors $\quad 14$

Analys is of Samples $\quad 15$

Counting Procedures 15

Vegetation Samples 15

Cesium-137 Determination 15

$\begin{array}{ll}\text { Tritium Determination } & 16\end{array}$

Water Samples 16

Cesium-137 Determination 16

Tritium Determination 16

Gross Beta Determination 16

$\begin{array}{lll}\text { Soil Samples } & 17\end{array}$

Sample Collection Data for Water, Vegetation, and Soil 17

Decennial Sampling of the Radioactive Disposal Area 18

Public Dose Assessment 22

Conclusions $\quad 24$

Sandia's National Security Responsibilities 26

Sandia's Participation in Energy Research and Development 27

$\begin{array}{ll}\text { Nuclear Energy } & 27\end{array}$

$\begin{array}{ll}\text { Radioactive Waste Products } & 27\end{array}$

Inertial Confinement Thermonuclear Fusion Research 27

Solar Energy Research $\quad 27$

Fossil and Geothermal Research 28

$\begin{array}{ll}\text { References } & 29\end{array}$ 
1 Vegetation Samples $\quad 17$

2 Uranium in Soil Samples $\quad 18$

3 Radioactive Disposal Area Soil Activity 19

4 Soil Moisture in the Radioactive Disposal Area 20

5 Tritium Concentration in the Soil Moisture of the 21 Radioactive Disposal Area

6 Pasquill Equation Results Used in Calculating Site 23 Boundary Concentrations

7 Radioactive Effluent Data 23

8 Dose Rates at Site Boundaries $\quad 25$

9 Annual Dose for the Albuquerque Area 26

Illustrations

Figure

1 Elevation Points Indicate the Topographical Relief of the Albuquerque Area

2 View of Sandia Technical Area I Looking SE Across Tijeras Arroyo Towards the Manzano Mountains 8

3 Sandia's Technical Areas I-V 9

4 Mesa Vegetation 10

5 Manzano Foothills Vegetation $\quad 10$ 


\section{SANDIA NATIONAL LABORATORIES 1979}

ENVIRONMENTAL MONITORING REPORT

Sandia Corporation which operates Sandia National Laboratories is a prime contractor to the Department of Energy (DOE). The Corporation, a subsidiary of Western. Electric, provides service to the U. S. Government on a no-profit, no-fee basis. Sandia's major responsibilities are national security and energy projects for DOE; the laboratories does however undertake work for other federal agencies on a non-interference basis.

Sandia Laboratories (Albuquerque, New Mexico)

\section{Location}

Sandia Laboratories is located in Albuquerque, New Mexico within the boundaries of Kirtland Air Force Base (KAFB). It sits on two broad mesas divided by Tijeras Arroyo. These mesas are surrounded by the Manzano mountains on the east and the Rio Grande on the west. The southern mesa is enclosed by Hell's Canyon wash to the south. The northern mesa continues into the city of Albuquerque. The mountains east of Sandia are part of the Cibola National Forest. The Isleta Indian reservation 1 ies south. It is sparse and little used.

The three elevation points in Figure 1 indicate the high topographical relief of the Albuquerque vicinity. Figure 2 is a view of Sandia National Laboratories looking southeast to the Manzano mountains. Figure 3 is a map of Sandia's technical areas: Areas I, II, and IV Iie on the northernmost mesa; Areas III and V lie on the southernmost mesa. 


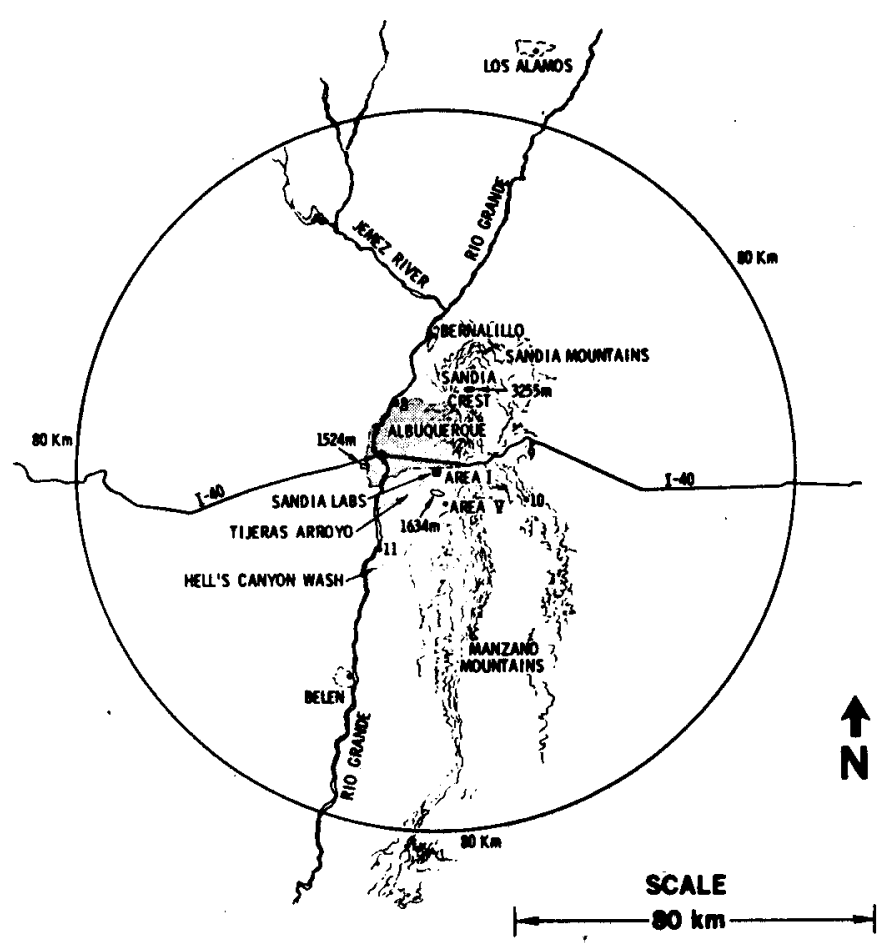

Figure 1. Elevation Points Indicate the Topographical Relief of the Albuquerque Area

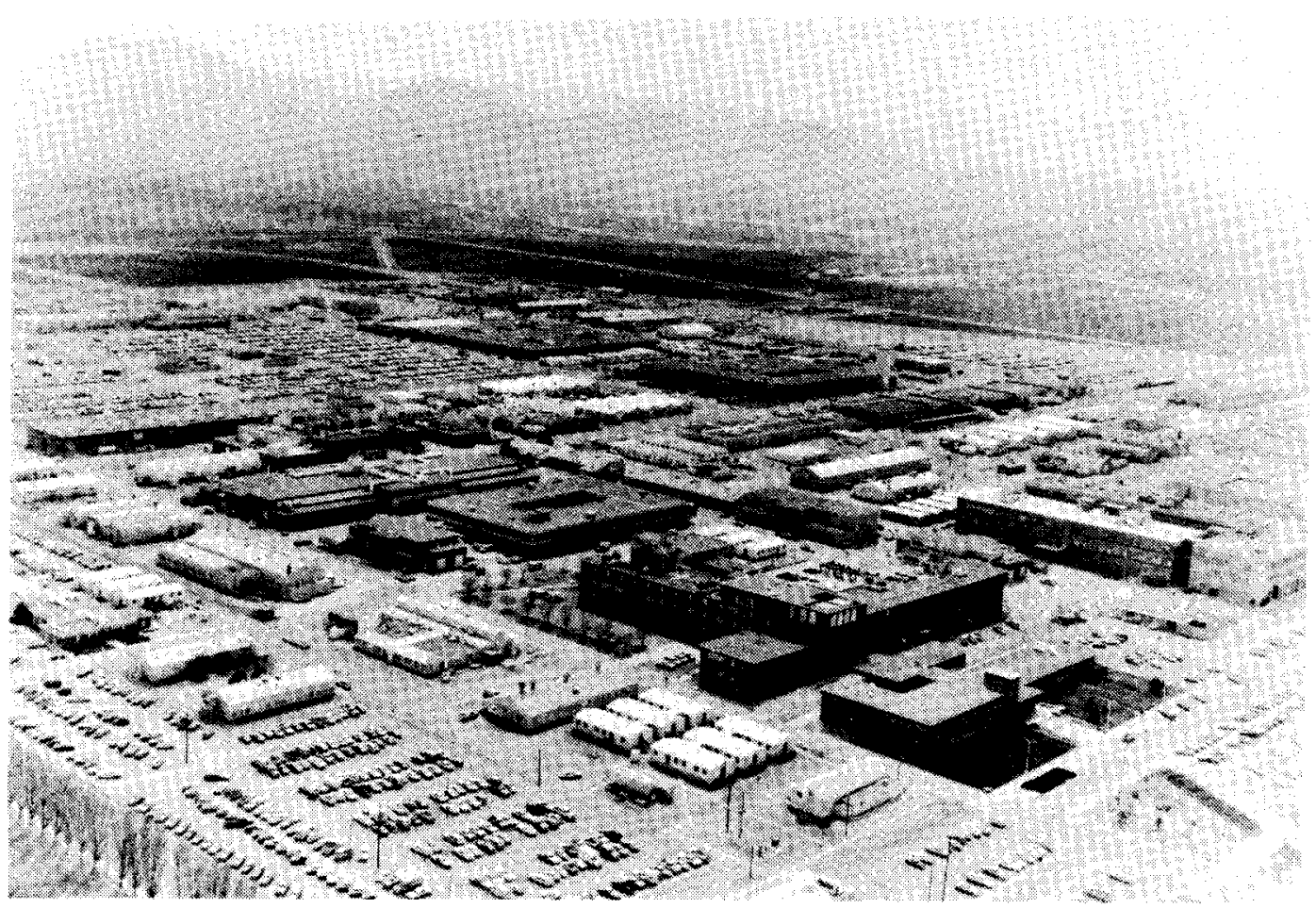

Figure 2. View of Sandia Technical Area I Looking Southeast Across Tijeras Arroyo Towards the Manzano Mountains 


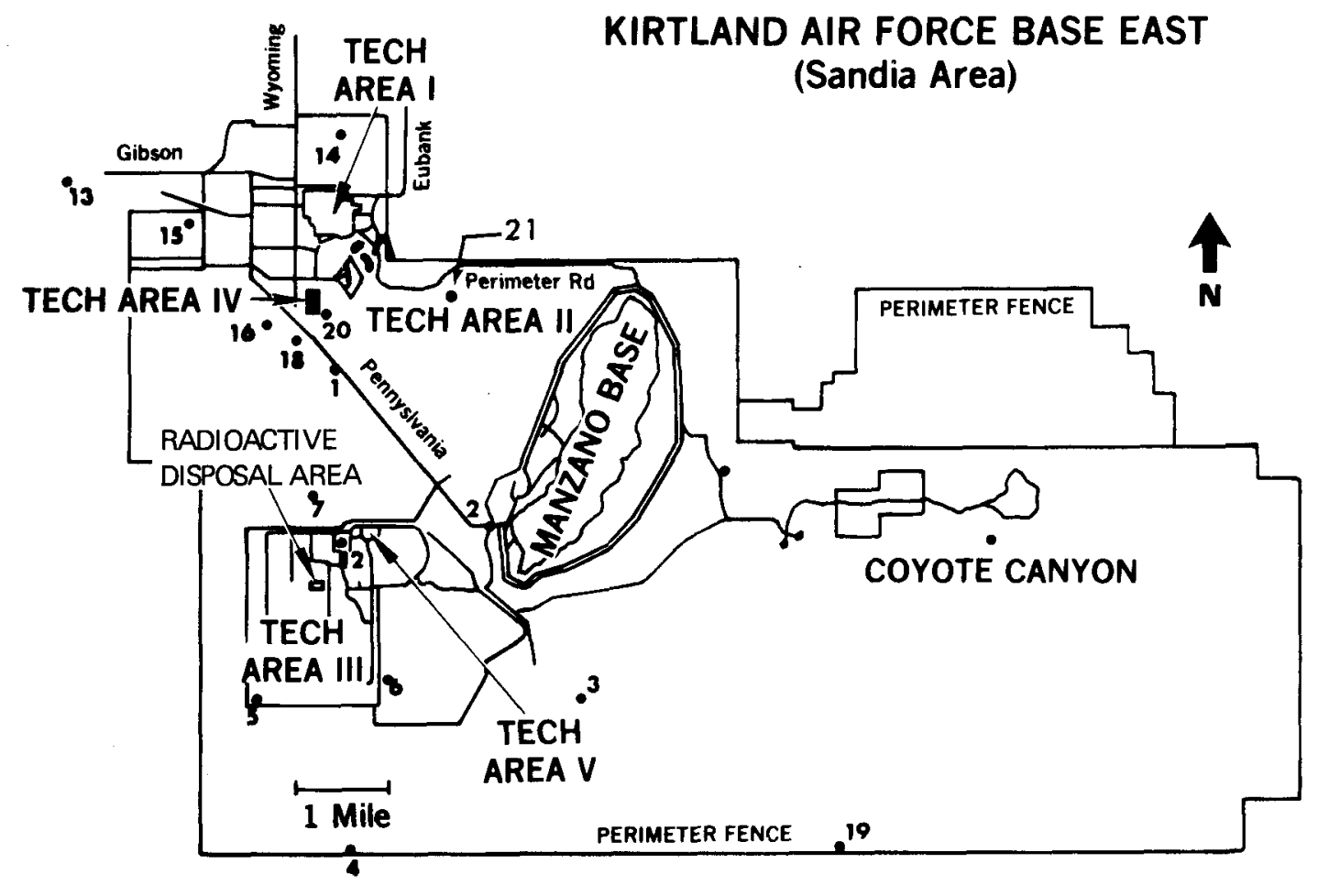

Figure 3. Sandia Technical Areas I-V

\section{Climate}

Albuquerque climate is "arid continental."l The mesa vegetation consists of grasses and drought resistant shrubs (see Figure 4). Juniper trees and cacti are present in higher elevation areas bordering the mountains (see Figure 5). Tumbleweeds (Russian Thistle) proliferate in mechanically disturbed areas. Roughly half of the $20 \mathrm{~cm}$ average annual rainfall comes during the months of July through September when thunderstorms are frequent. Winter months are quite dry. Daily temperature ranges are wide, but extreme temperatures 1 ike $-18^{\circ}$ and $38^{\circ} \mathrm{C}$ occur infrequently. Strong winds, often accompanied by blowing dust, occur mostly in late winter and early spring. The wind speed reaches $13.3 \mathrm{~m} / \mathrm{s}$ less than 48 days each year. In Area $V$ the prevailing wind blows from a quadrant bounded by the southwest and northwest. The water table 1 ies $137 \mathrm{~m}$ below Area $V$. There are indications that the ground water flows westward towards the Rio Grande in the vicinity of Area $V .{ }^{1}$ Because of infrequent stream flow (there are no continuously running streams on KAFB), municipal and domestic water needs of the Albuquerque vicinity are supplied by deep 
wel1s (most are $305 \mathrm{~m}$ deep with a range of 148-365 m). Rio Grande water is used for agricultural irrigation.

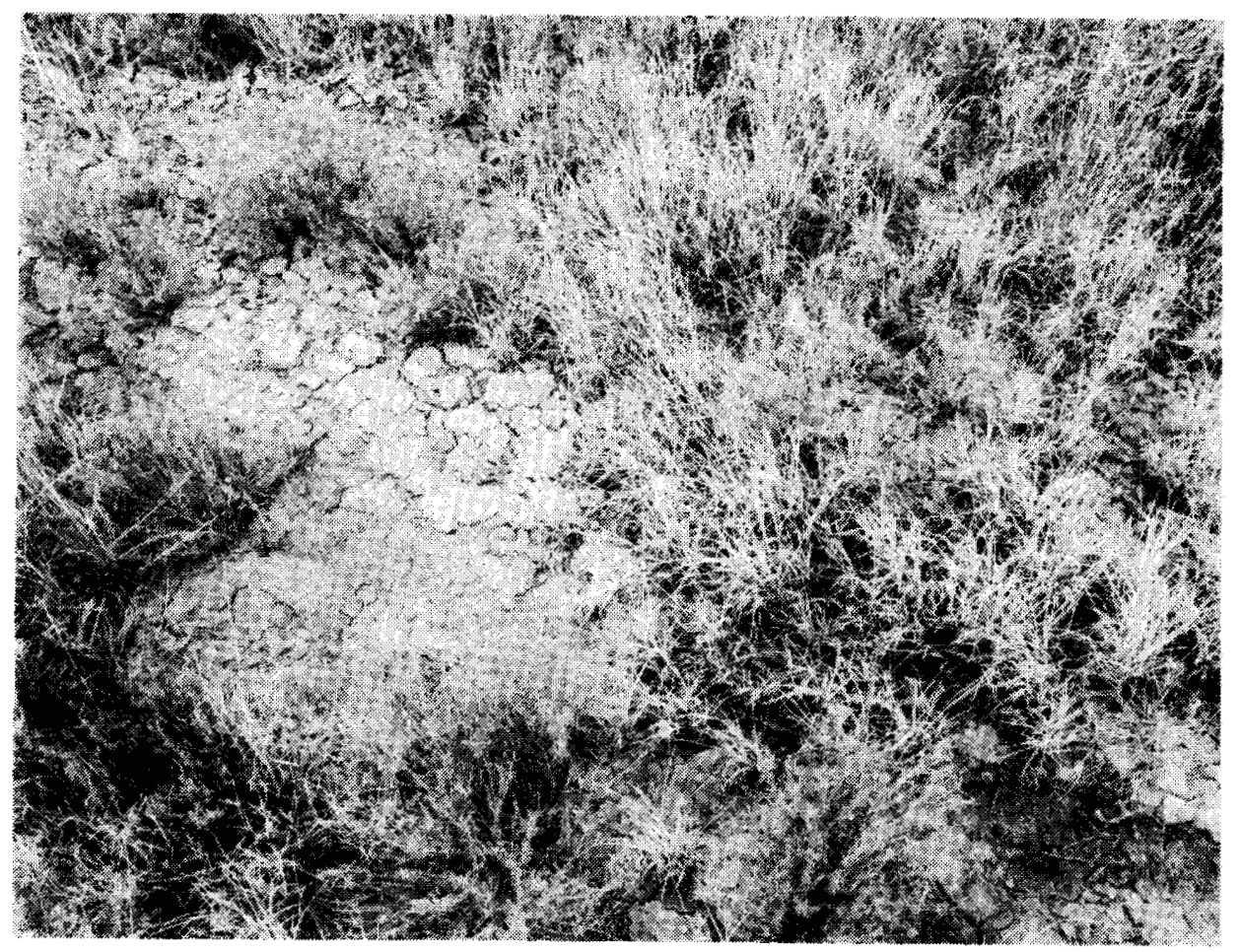

Figure 4. Mesa Vegetation

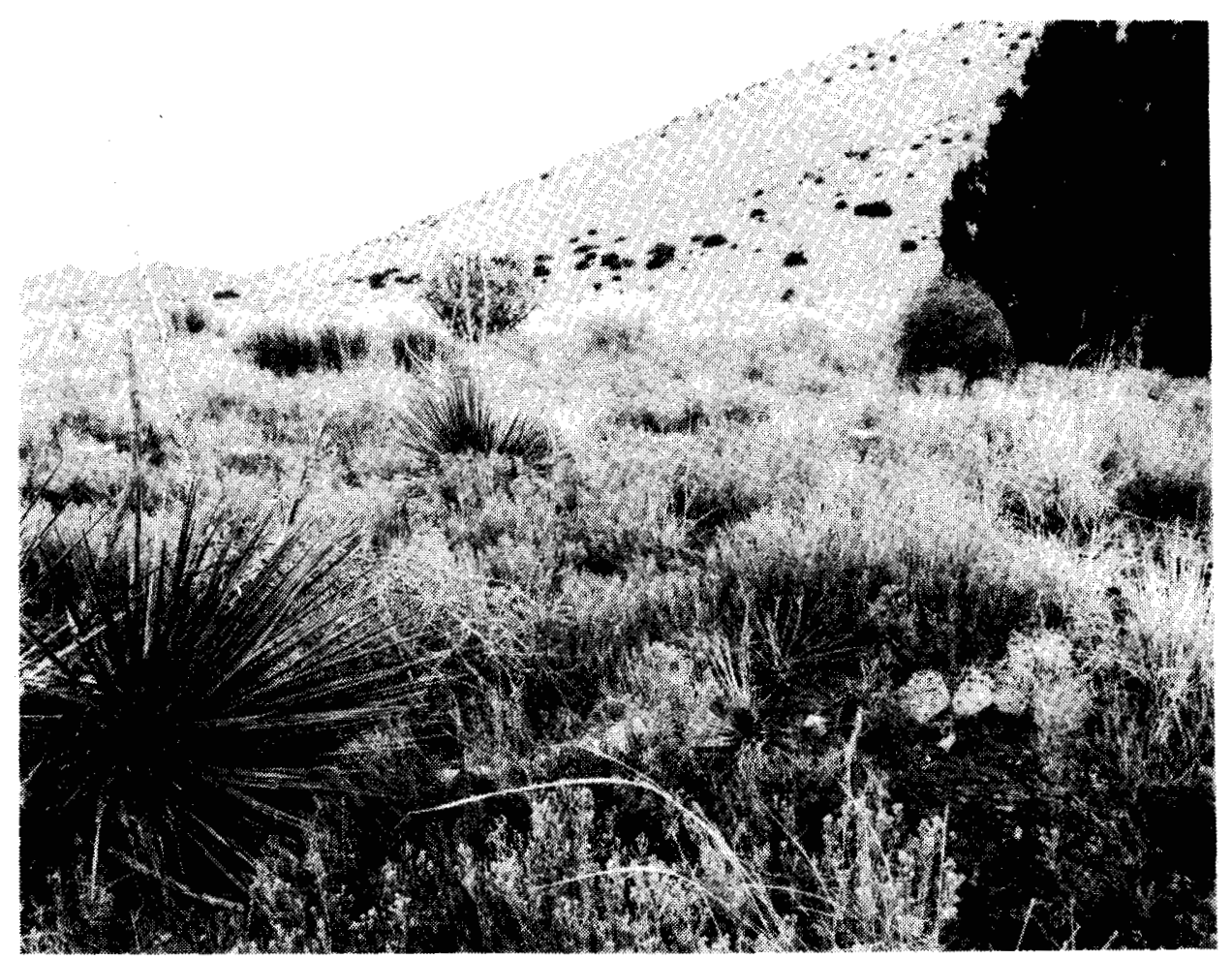

Figure 5. Manzano Foothil1s Vegetation 
Because radionuclides are released as a result of Sandia's nuclear research and because these releases occur in many locations, we will include in this section not only a physical description of facilities in Sandia's five technical areas but a summary of radioactive material released in each area.

Technical Area I has the largest population of the five technical areas. It houses administrative as well as support functions in its laboratories and shops. Tritium from two sources is the only radioactive material released from this area.

Small explosive tests are conducted in Technical Area II. Techniques for measuring fractures in geological strata are developed in this Area. $\mathrm{Kr}-85$ is vented from the earth during field tests.

Technical Area III has a sludge irradiation facility and extensive environmental test facilities. The latter include sled tracks, centrifuges, and a radiant heat facility. Sandia disposes solid, low-level radioactive wastes in pits and trenches located in this area. No Area III activity releases a radioactive effluent.

Technical Area IV is a new area housing inertial confinement fusion research facilities. Two large accelerators to produce electrons or 1 ight ions are near completion here, One, the Particle Beam Fusion Accelerator (PBFA) will be used to shoot deuterium-tritium pellets. Gaseous tritium effluents will be generated in the research. There are no current radioactive releases from this area.

Technical Area $V$ houses large electron beam accelerators, two research reactors, an intense gamma irradiation facility (using Co-60 and Cs-137), a neutron irradiation facility (using Cf-252), and a hot cell facility (for handling transuranic materials and intensely radioactive materials). Tritium is released from the accelerators when they are used 
for fusion research. Argon-41 is released from the reactors. The two research reactors in Area $V$ are quite dissimliar. The Sandia Pulsed Reactor (SPR) is an unreflected, unmoderated assembly of enriched uranium. The Annular Core Research Reactor is an annular core of 226 fuel elements in an open water tank. Both SPR and ACRR air exhaust systems are equipped with particulate effluent samplers. ACRR also has a continuous gaseous effluent monitor. No measureable radioactivity was released by the two reactors in 1979. The reported amount of Ar-41 was computed from reactor operating parameters. Neither ACRR nor SPR release cooling water.

Sandia has environmental test areas outside of the five technical areas. These areas are located south of Area III and in canyons on the eastern side of the Manzano mountains. Coyote Canyon (Figure 3) is such an area. In these remote areas, depleted uranium is infrequently spread over 1 imited areas during explosive testing. It is not possible for these releases to reach public areas.

\section{Monitoring for Radioactive Material}

The environmental monitoring effort at Sandia Laboratories began in February of 1959. The program is designed to detect the release and/or migration of radioactive material. Soil, vegetation, we11-water, and air (with passive fallout collectors) is monitored. Because of the arid climate and accompanying deep water table, no transport of radioactive material to public areas by water is expected, nor has any been detected. 2-9 Nuclides searched for in the monitoring program are cs-137 and tritium. Cesium-137 is a fission product produced abundantly in reac-tor fuel and is completely contained therein. Sandia analyzes water and vegetation samples for Cs-137 to provide a final check on all reactor radiological safety systems (such as containment, alarm and monitoring systems, and exhaust air filtration). Gross alpha and gross beta measure-ments in water samples provide an additional check. Water and vegetation samples also are monitored for tritium soil samples are analyzed for uranium to determine the existence or spread of uranium. 
Except for site 22 the following environmental sampling sites can be located in Figures 1 and 3 .

1. Pennsylvania Avenue and Tijeras Arroyo between the southwest side of the bridge and the truck bypass.

2. Manzano Base main gate.

3. Coyote Canyon control area (vicinity of Building 9925).

4. Isleta Reservation gate.

5. McCormick Range (now McCormick Gate). The samples at this site are taken from the southwest corner of the Area III perimeter fence.

6. Old Area III gate - east of Area III perimeter fence at Building 6501 .

7. Arroyo (aqueduct) north of Area III.

8. Corrales Bridge - east side of bridge, north of street (Figure 1).

9. Sedillo Hill - Comer's Cafe and Service Station (Figure 1).

10. Oak Flats picnic area on south State Highway 14 (Figure 1).

11. Isleta Pueblo at irrigation control gates on the east side of the river (Figure 1).

12. Area III we11.

13. Base wel1 Number 1 (East).

14. Base well Number 2 .

15. Base well Number 3 .

16. Base well Number 4.

17. Base we11 Number 6 .

18. Base wel1 Number 8 .

19. Seismic Center gate.

20. Area IV power substation. 
21. Base wel1s Numbers 11 and 12 .

22. Base wel1 Number 14 .

Samples are gathered, stored, and analyzed in accordance with ERDA-7724, A Guide for Environmental Radiological Surveillance at ERDA Insta1lations to the extent local conditions permit. In 1979 all vegetation samples were taken the first week of October. Water samples were drawn at the end of October. Environmental samples are gathered at the end of the growing season. Soil and vegetation samples are collected from a $3 \times 3$ meter area at each site. This is true for all but well sites. Three or four samples of the upper $5 \mathrm{~cm}$ of soil are gathered and composited.

About $0.5 \mathrm{~kg}$ of the aerial portion (stems and leaves) of vegetation, characteristic of the sample site, is collected at each location. The sample is stored in a plastic bag with ample air to prevent decomposition before analysis. Little decomposition is possible, however, because of sample dryness. From water wells and the Rio Grande, two litres of water are collected in acid-cleansed plastic jugs that have been rinsed with distilled water.

\section{$\underline{\text { Fallout Collectors }}$}

In 1977 four passive, fallout collectors were erected in the northwest, northeast, southeast and southwest corners of Area V. A fifth collector is located in Area III at the predicted point of maximum mean concentration from the Area $V$ stack. A sixth is located $16 \mathrm{~km}$ north of Area $V$ in an Albuquerque residential area. This sixth collector provides local background data.

The collectors were built to gather local background data prior to startup of a hot cell facility. For each collector the facility has not yet handled the radioactive materials for which it was built. When the facility begins to use these materials, the six pot collectors will provide environmental monitoring. 
The collectors are emptied every two to three months. Material from the collectors is analyzed for alpha and beta activity. The material's gamma emission spectrum is then determined. Comparing data from the Area III and $V$ collectors, the background data, and the previous sampling data provides a qualitative check on hot-cell radiological safety systems. These systems include radiation monitors, containment and filtered exhaust.

A barely detectable quantity of Rh-109 was found in the $\mathrm{NE}$ corner of Area V, following a sample collection on June 15, 1977. The Rh-109 was attributed to nuclear weapons fallout. No other abnormal concentrations of radionuclides have been found in the collectors since. Data from the collectors will not be presented in this report since no calculations of air concentrations or health effects can be made from it.

\section{Analys is of Samples}

Counting Procedures -- Background leve1 and counter efficiency are determined during each counting run; thus, any abnormal variation is noticed, and corrective action is taken. Counter efficiencies are obtained by reference to standard sources.

Samples are counted for beta activity by using a gas proportional chamber with a thin window. During each counting cycle, a samplers background, and a standard source are counted in a prescribed sequence which provides all required information for interpretation of results in terms of disintegrations per minute.

Vegetation Samples -- A vegetation sample is mixed and finely cut in a commercial-type blender. Aliquots of the blended vegetation are taken for each radiochemical analysis.

Cesium-137 Determination. A $10 \mathrm{~g}$ aliquot of vegetation is reduced to a fine gray ash in a muffle furnace at $450^{\circ} \mathrm{C}$. The ash is treated with nitric acid to dissolve the cesium. The resulting solution is filtered. The filtrate is passed through an ion-exchange of KCFC (inorganic 
ion-exchange resin, potassium hexacyanocobalt II ferrate) which absorbs the cesium. The ion-exchange column containing the cesium is then counted in a gamma well counter.

Tritium Determination. A weighed aliquot of blended vegetation is combusted in a stream of oxygen. Water is removed from the combustion exhaust and collected for liquid scintillation counting.

Water Samples -- Aliquots of the two-1itre water sample are taken for radionuclide analysis.

Cesium-137 Determination. Water is passed through a KCFC ionexchange column to remove any cesium. The resin containing the cesium is gamma-counted.

Tritium Determination. Water samples are counted using liquid scintillation to determine the presence or absence of tritium.

Gross Beta Determination. The hardness of the water is determined so that after evaporation no more than $7 \mathrm{mg} / \mathrm{cm}^{2}$ of solids will be in the final deposit. (Heavier deposits require greater correction for selfabsorption of beta activity.) Water is filtered through a hydrosol-type membrane filter $(0.45 \mu \mathrm{m})$. The filter is saved for a gross beta count of suspended solids. The filtrate is acidified with nitric acid, evaporated to a small volume, and transferred to a tared, stainless-steel planchet. The water is then completely evaporated, and the residue is weighed and beta-counted.

The membrane filter is placed in a tared, stainless steel planchet (with solids down against the planchet), then the filter is dissolved in acetone, and the acetone is burned off. The planchet containing the suspended solids from the water sample is reweighed and beta-counted. Combined dissolved and suspended solids activity is reported. 
Soil Samples -- A soil sample is mixed, ball-milled, then sieved. A weighed aliquot is treated with nitric acid to remove uranium. Total uranium content is determined using fluorimetric methods.

Sample Collection Data for Water, Vegetation, and Soil -- Water samples were collected from sites 8,11-18 (see page 13). Gross beta activity at these sites was less than the minimum detectable limit (MDL) of $8.7 \times 10^{-9} \mu \mathrm{Ci} / \mathrm{mL}$. This MDL is $87 \%$ of the Radiation Concentration Guide (RCG) of $1 \times 10^{-8} \mu \mathrm{Ci} / \mathrm{mL}$. Cesium-137 activity was less than the MDL of $5.1 \times 10^{-8} \mu \mathrm{Ci} / \mathrm{mL}$. This $\mathrm{MDL}$ is $0.7 \%$ of the RCG of $7 \times 10^{-6} \mu \mathrm{Ci} / \mathrm{mL}$. Tritium activity was less than the MDL of $4.5 \times 10^{-7} \mu \mathrm{Ci} / \mathrm{mL}$. This $\mathrm{MDL}$ is $0.05 \%$ of the RCG of $1 \times 10^{-3} \mu \mathrm{Ci} / \mathrm{mL}$. Radiation Concentration Guides for gross beta activity, $\mathrm{Cs}^{-137}$, and tritium are taken from the "Standards for Radiation Protection", USERDA Manual, Appendix 0524.

Data obtained from vegetation and soil samples collected for this report are summarized in Tables 1 and 2 .

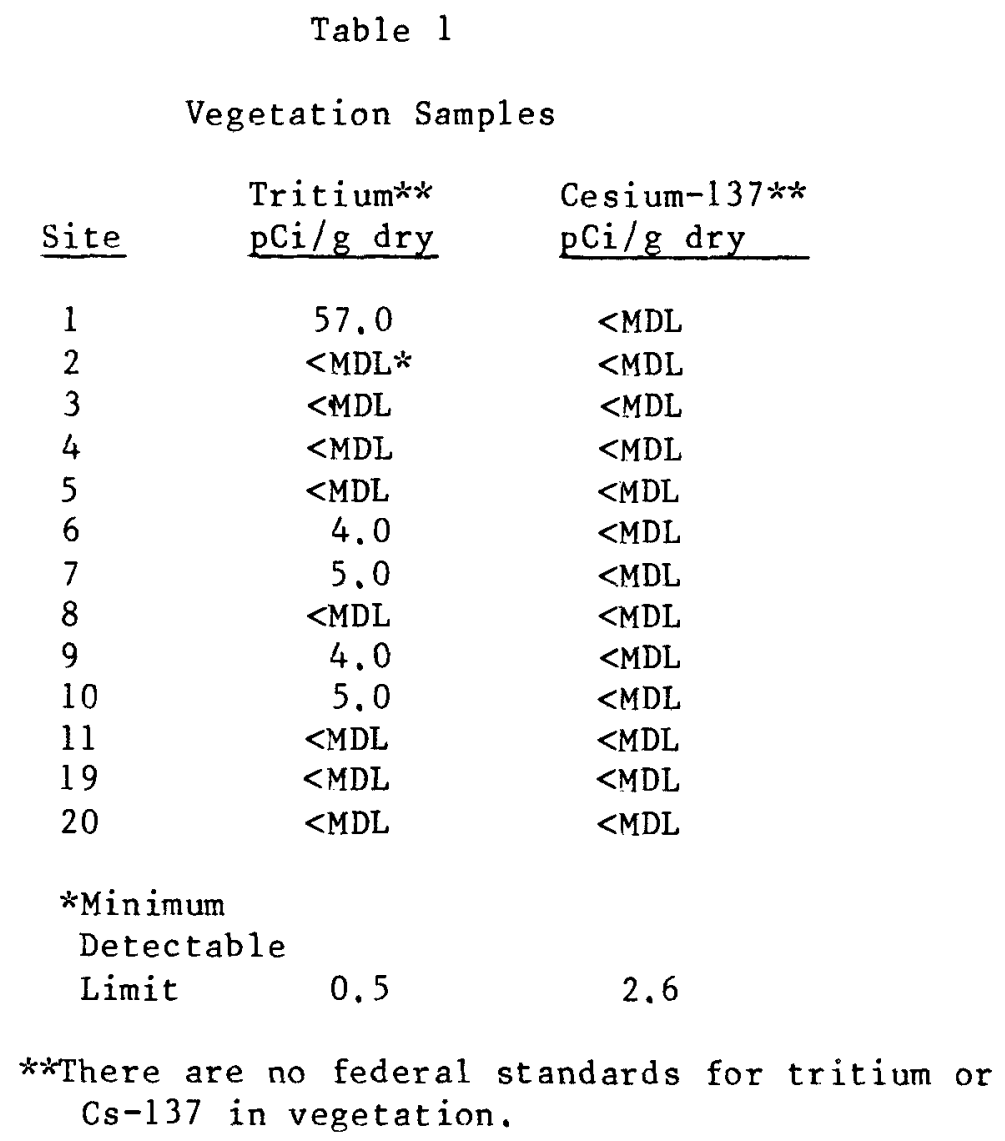


Table 2

Uranium in Soil Samples

$\begin{array}{lc}\text { Site } & \mu \mathrm{U} / \mathrm{g} \text { Dry So: * } \\ 1 & 0.031 \\ 2 & 0.018 \\ 3 & <\mathrm{MDL} * \\ 4 & 0.014 \\ 5 & <\mathrm{MDL} \\ 6 & 0.010 \\ 7 & 0.014 \\ 8 & 0.050 \\ 9 & 0.021 \\ 10 & 0.021 \\ 11 & 0.150 \\ 19 & 0.021 \\ 20 & 0.031 \\ \text { *Minimum } & 0.010 \\ \text { Detectable } & \\ \text { Limit } & \\ \text { *** There are no federal standards for } \\ \text { uranium in soil. }\end{array}$

Decennial Sampling of the Radioactive Disposal Area -- In 1969 core samples were taken around the radioactive waste disposal area (Figure 3 ). 4 These samples were collected at depths of $7.6 \mathrm{~m}(25 \mathrm{ft})$ and $15.2 \mathrm{~m}(50 \mathrm{ft})$ at five locations on the disposal area perimeter. The sample cores were analyzed for gross beta activity, total strontium, Cs-137, and gamma activity. There was no evidence of radionuclide migration from the disposal area.

In 1979 thirty-five soil samples were taken as a part of an ion migration study. These were collected from a single pit, dug five feet from a field of thirty-two pits containing tritium waste. They were taken at 0.3 ( $1 \mathrm{ft}$ ) intervals to a depth of $11 \mathrm{~m}(35 \mathrm{ft})$. The samples were coated to avoid water loss before analysis, and were analyzed for gross beta activity, gross alpha activity, total uranium, and tritium. Al1 the samples were retained. Table 3 presents the results. 
Table 3

Radioactive Disposal Area Soil Activity

\begin{tabular}{|c|c|c|c|c|}
\hline $\begin{array}{l}\text { Depth } \\
\text { (Meters) }\end{array}$ & $\begin{array}{l}\text { Alpha Activity } \\
\mathrm{pCi} / \mathrm{g} \text { Dry Soil }\end{array}$ & $\begin{array}{l}\text { Beta Activity } \\
\mathrm{pCi} / \mathrm{g} \text { Dry Soil }\end{array}$ & $\begin{array}{l}\text { Tritium } \\
\mathrm{pCi} / \mathrm{g} \text { Dry Soi } 1\end{array}$ & $\begin{array}{l}\text { Uranium } \\
\mathrm{g} / \mathrm{g} \text { Dry soil }\end{array}$ \\
\hline 0.3 & 0.2 & $<M D L$ & 0.5 & $<M D L^{*}$ \\
\hline 0.6 & 0.2 & 0.1 & 1.8 & $<M D L$ \\
\hline 0.9 & 0.5 & $<M D L$ & $<M D L$ & $<M D L$ \\
\hline 1.2 & $<\mathrm{MDL}$ & 1.0 & $<\mathrm{MDL}$ & $<M D L$ \\
\hline 1.5 & 0.9 & 0.2 & $<\mathrm{MDL}$ & $<M D L$ \\
\hline 1.8 & 0.2 & 0.5 & 4.5 & $<M D L$ \\
\hline 2.1 & 0.7 & 1.4 & $<M D L$ & $<M D L$ \\
\hline 2.4 & 0.2 & 1.0 & 3.6 & $<M D L$ \\
\hline 2.7 & $<M D L$ & 1.7 & 6.8 & $<M D L$ \\
\hline 3.0 & 0.2 & 0.2 & $<M D L$ & $<M D L$ \\
\hline 3.4 & 0.5 & $<M D L$ & 3.6 & $<M D L$ \\
\hline 3.7 & 0.2 & $<M D L$ & 1.4 & $<M D L$ \\
\hline 4.0 & 0.5 & 0.6 & 0.9 & $<M D L$ \\
\hline 4.3 & 0.2 & 0.1 & $<\mathrm{MDL}$ & $<\mathrm{MDL}$ \\
\hline 4.6 & 0.7 & $<M D L$ & 2.7 & $<M D L$ \\
\hline 4.9 & 0.2 & 0.9 & 12.6 & $<M D L$ \\
\hline 5.2 & 0.2 & 0.7 & $<M D L$ & $<M D L$ \\
\hline 5.5 & 0.5 & 1.0 & 9.9 & $<\mathrm{MDL}$ \\
\hline 5.8 & 0.7 & 0.6 & 4.1 & $<M D L$ \\
\hline 6.1 & $<M D L$ & 0.2 & 0.9 & $<\mathrm{MDL}$ \\
\hline 6.4 & $<M D L$ & 0.9 & $<M D L$ & $<M D L$ \\
\hline 6.7 & 0.2 & 0.7 & 6.8 & $<M D L$ \\
\hline 7.0 & 0.2 & 0.4 & 15.3 & $<M D L$ \\
\hline 7.3 & 0.2 & 0.5 & $<\mathrm{MDL}$ & $<\mathrm{MDL}$ \\
\hline 7.6 & 0.7 & 1.3 & 6.3 & $<M D L$ \\
\hline 7.9 & $<M D L$ & 0.4 & $<M D L$ & $<M D L$ \\
\hline 8.2 & $<M D L$ & 0.7 & 3.6 & $<M D L$ \\
\hline 8.5 & 0.2 & 0.9 & 1.4 & $<M D L$ \\
\hline 8.8 & 0.7 & 8.7 & 6.3 & $<M D L$ \\
\hline 9.1 & 0.5 & 0.4 & 8.1 & $<M D L$ \\
\hline 9.4 & 0.9 & 0.7 & 9.5 & $<M D L$ \\
\hline 9.8 & $<M D L$ & 0.9 & 7.7 & $<M D L$ \\
\hline 10.1 & $<M D L$ & 0.9 & 6.8 & $<M D L$ \\
\hline 10.4 & 0.2 & 0.2 & 1.8 & $<M D L$ \\
\hline 10.7 & 0.5 & 1.4 & 6.8 & $<M D L$ \\
\hline \multicolumn{5}{|l|}{${ }^{*}$ Minimum } \\
\hline \multicolumn{5}{|c|}{ Detectable } \\
\hline Limit & 0.2 & 0.1 & 0.5 & 0.010 \\
\hline
\end{tabular}


No uranium was found at any depth. Alpha activity showed no variation with depth. Beta activity was mostly uniform with depth, the exception being the $8.8 \mathrm{~m}$ sample which was 10.5 times higher than the mean. This sample has been resubmitted for analysis. Tritium does not show uniformity with depth. There is more tritium (at $95 \%$ confidence comparing group means of tritium per gram in dry soil) below the $6.1 \mathrm{~m}$ (20 $\mathrm{ft}$ ) level than above. Pits and trenches in the disposal area are $6.1 \mathrm{~m}$ deep. Thus, there is reason to suspect that tritium has moved from the disposal pits. Soil moisture decreased with depth (see Table 4). Therefore, the tritium concentration in the moisture of the soil increased with depth more rapidly than the tritium data of Table 3 might indicate.

Table 4

Soil Moisture in the Radioactive Disposal Area

\begin{tabular}{lc}
$\begin{array}{l}\text { Depth } \\
\text { (Meters) }\end{array}$ & $\begin{array}{c}\text { Moisture Content } \\
(\% \text { by Weight })\end{array}$ \\
\hline
\end{tabular}

0-0. 6

6.17

$0.6-1.2$

5.93

1. $2-1.8$

5.43

$1.8-2.4$

4.93

2. $4-3.0$

7.92

$3.0-3.7$

3.10

3. $7-4.3$

6.60

4. 3-4. 9

5.31

4. $9-5.5$

4.31

$5.5-6.1$

4.36

6.7

3.98

$6.7-3.7$

3.79

7. 3-7. 9

3.26

$7.9-9.1$

3.07

9.1-9.9

2.84

10.7

3.07

11.4

2.75

12.2

2.84

15.2

1.89

In Table 5 the soil moisture data of Table 4 is combined with the tritium data of Table 3 to produce data on tritium concentrations in soil moisture. Since the sampling for soil moisture was at coarser increments 
than sampling for radioactivity, some arbitrary assignments of soil moisture was necessary. None of the soil samples contained moisture with tritium concentrations above the applicable radiation concentration guide.

Table 5

Tritium Concentration in the Soil Moisture of the Radioactive Disposal Area

\begin{tabular}{|c|c|c|}
\hline Depth in Meters & $\mu \mathrm{Ci} / \mathrm{mL}$ & Percent of Standard* \\
\hline 0.3 & $6.85 \times 10^{-6}$ & 0.7 \\
\hline 0.6 & $2.86 \times 10^{-5}$ & 3 \\
\hline 0.9 & 0 & 0 \\
\hline 1.2 & 0 & 0 \\
\hline 1.5 & 0 & 0 \\
\hline 1.8 & $8.69 \times 10^{-5}$ & 9 \\
\hline 2.1 & 0 & 0 \\
\hline 2.4 & $4.19 \times 10^{-5}$ & 4 \\
\hline 2.7 & $7.86 \times 10^{-5}$ & 8 \\
\hline 3.0 & 0 & 0 \\
\hline 3.4 & $1.13 \times 10^{-4}$ & 11 \\
\hline 3.7 & $1.91 \times 10^{-5}$ & 2 \\
\hline 4.0 & $1.27 \times 10^{-5}$ & 1.3 \\
\hline 4.3 & 0 & 0 \\
\hline 4.6 & $4.82 \times 10^{-5}$ & 5 \\
\hline 4.9 & $2.8 \times 10^{-4}$ & 28 \\
\hline 5.2 & 0 & 0 \\
\hline 5.5 & $2.17 \times 10^{-4}$ & 22 \\
\hline 5.8 & $8.89 \times 10^{-5}$ & 9 \\
\hline 6.1 & $1.09 \times 10^{-5}$ & 1.1 \\
\hline 6.4 & 0 & 0 \\
\hline 6.7 & $1.72 \times 10^{-4}$ & 17 \\
\hline 7.0 & $3.89 \times 10^{-4}$ & 39 \\
\hline 7.3 & 0 & 0 \\
\hline 7.6 & $1.87 \times 10^{-4}$ & 19 \\
\hline 7.9 & 0 & 0 \\
\hline 8.2 & $1.14 \times 10^{-4}$ & 11 \\
\hline 8.5 & $4.27 \times 10^{-5}$ & 4 \\
\hline 8.8 & $1.99 \times 10^{-4}$ & 20 \\
\hline 9.1 & $2.77 \times 10^{-4}$ & 28 \\
\hline 9.4 & $3.24 \times 10^{-4}$ & 32 \\
\hline 9.8 & $2.62 \times 10^{-4}$ & 26 \\
\hline 10.1 & $2.18 \times 10^{-4}$ & 22 \\
\hline 10.4 & $5.83 \times 10^{-5}$ & 6 \\
\hline 10.7 & $2.13 \times 10^{-4}$ & 21 \\
\hline
\end{tabular}

${ }^{\star}$ St andards for Radiation Protection, USERDA Manual, Appendix 0524. 
Groundwater near the surface has tritium concentrations of the precipitation falling on the ground. ${ }^{10}$ Global precipitation averages $4 \times 10^{-9} \mu \mathrm{Ci} / \mathrm{mL}$ from tritium produced mainly by cosmic radiation. Residual tritium from nuclear weapons testing dominates this source by at least a factor of ten. ${ }^{11}$ Furthermore, half of the fallout was between $30^{\circ}$ and $50^{\circ} \mathrm{N} .10$ Thus, one would expect to find near-surface soil moisture in Albuquerque having tritium concentrations of at least $4 \times 10^{-8} \mu \mathrm{Ci} / \mathrm{m} 1$. Reference 12 reports a value of $2.87 \times 10^{-7} \mu \mathrm{Ci} / \mathrm{ml}$ for surface water in the region between $30^{\circ}$ and $50^{\circ} \mathrm{N}$ latitude, which includes Albuquerque. The highest concentration found inside the radiactive disposal area was $3.89 \times 10^{-4} \mu \mathrm{Ci} / \mathrm{ml}$, much higher than the $2.87 \times 10^{-7} \mu \mathrm{Ci} / \mathrm{mI}$ expected for near-surface ground water.

We have insufficient knowledge of local conditions to properly assess the tritium data. Additional sampling is being initiated to investigate the matter, and the results will be reported in future environmental reports.

Public Dose Assessment -- Airborne concentrations of argon-41 and tritium resulting from SLA emissions are too low to be measured in public locations. These concentrations are therefore estimated using Pasquil1's atmospheric diffusion equations, ${ }^{13}$ estimated amounts of radionuclides released, and assumed meteorological conditions. There estimated concentrations allow a dose estimate to be made at site boundaries and for the Albuquerque area population as a whole.

The following is Pasquill's Gaussian diffusion equation:

$$
x=\frac{f Q}{\pi \sigma_{y} \sigma u} \exp \left[\left(\frac{y^{2}}{2 \sigma y^{2}}+\frac{h^{2}}{2 \sigma_{z}^{2}}\right)\right]
$$

where

$$
\begin{aligned}
& Q=\text { source strength in curies per second } \\
& \mathrm{u}=\text { mean wind speed in metres per second } \\
& \mathrm{y}=\text { receptor location in metres from the plume axis }
\end{aligned}
$$




$$
\begin{aligned}
\mathrm{h} & =\text { source height in metres } \\
\sigma_{\mathrm{y}} \sigma_{\mathrm{z}}= & \text { diffusion coefficiencies in metres. These } \\
& \text { coefficients a function of distance from the stack } \\
\mathrm{f} & =\text { frequency the wind blows in the given direction } \\
\mathrm{x} & =\text { concentration in curies per cubic metre }
\end{aligned}
$$

A neutral Type D Pasquill meteorological condition is assumed. A wind speed of $4 \mathrm{~m} / \mathrm{s}$ is assumed which is compatible with Type D conditions. A conservative simplifying assumption that $y=0$ and $h=0$ is also made. The maximum mean time the wind blows in a given direction is $11.4 \%$ (based on 10 years of data). 14 Reference 15 gives less conservative data for comparison, but will not be used. These parameters are used in Eq. 1 to generate the results in Table 6. The results in Table 7 are used in both site boundary dose calculations and Albuquerque population dose calculations.

Table 6

$\begin{aligned} & \text { Pasquil Equation Results Used in Calculating } \\ & \text { Site Boundary Concentrations }\end{aligned}$
$\begin{array}{cc}\begin{array}{l}\text { Distance from } \\ \text { Release Point }(\mathrm{m})\end{array} & \frac{(\mathrm{s} / \mathrm{mL})}{50} \\ 600 & 2.52 \times 10^{-9} \\ 3000 & 7.86 \times 10^{-11} \\ 80000 & 5.37 \times 10^{-13} \\ 2.27 \times 10^{-16}\end{array}$

Table 7

Radioactive Effluent Data

$\begin{array}{cccc}\text { Release Site } & \text { Effluent } & \frac{\text { Ci Released }}{3_{\mathrm{H}}} & \begin{array}{c}\text { Release Rate } \\ (\mu \mathrm{Ci} / \mathrm{s})\end{array} \\ \text { Area I } & { }^{85} \mathrm{Kr} & 0.11 & 9.86 \times 10^{-2} \\ \text { Area II } & { }^{4} \mathrm{Ar} & 5.51 & 2.38 \times 10^{-3} \\ \text { Area V } & { }^{\mathrm{H}} & 3 & 0.175 \\ \text { Area V } & { }^{\mathrm{H}} & & 9.51 \times 10^{-2}\end{array}$


The release rates $(Q)$ of tritium, ${ }^{85} \mathrm{Kr}$ and ${ }^{41} \mathrm{Ar}$ from the radioactive effluent data (Table 7 ) were multiplied by the $X / Q^{\prime}$ s of Table 6 . These products were then used to calculate dose rates at site boundaries (Table 8). For each radionuclide, we used a dose rate conversation factor (DRCF), based on the Radiation Concentration Guides (RCG) of Table 8.

The results of dose calculations for the Albuquerque area are given in Table 9. The $80 \mathrm{~km}$ radius area has 380000 people (assumed to be living in a uniformly populated inner $20 \mathrm{~km}$ radius). Equation 2 is used to calculate population doses.

$$
\frac{3.8 \times 10^{5}}{\pi(20 \mathrm{~km})^{2}} \int_{0 \mathrm{~km}}^{20 \mathrm{~km}} \times(\text { DRCF }) \quad 2 \mathrm{r} \pi \mathrm{d} \mathbf{r}
$$

The integral in Eq. 2 overestimates ${ }^{41} \mathrm{Ar}$ dose, as it does not include the 1.83 hour half-1ife decay of the nuclide as it traverses the $20 \mathrm{~km}$.

\section{Conclusions -- No anomalous concentrations of radionuclides were} found in well water. Cesium-137, if present, was at concentrations of less than $0.7 \%$ of the RCG. Tritium, if present, was at concentrations of less than $0.05 \%$ of RCG. Other beta emitters, if present, were at concentrations of less than $87 \%$ of the RCG. During the span of Sandia's Environmental Monitoring Program (which began in 1959) the range of gross beta measured in water has been 0 to $2527 \mu \mathrm{Ci} / \mathrm{mL} .{ }^{2-9}$ Samples taken in 1979 fall in the low end of this range and should be considered background.

No Cs-137 was detected in vegetation. Site 1 (see page 13) had an elevated level of tritium in its vegetation. All other sites were below or near detection limits. The uranium data in Table 3 for uranium soil content is below the average earth crustal concentration of $0.76 \mu \mathrm{g} / \mathrm{g} .16$ In 1979, passive fallout collectors gathered only natural background radionuclides. 
Table 8

Dose Rates at Site Boundaries

$\begin{array}{cccc}\text { Nuclide } & \begin{array}{c}\text { Distance to } \\ \text { Site_Boundary }\end{array} & \begin{array}{c}\text { Boundary } \\ \text { Concentration } \\ (\mu \mathrm{Ci} / \mathrm{mL})\end{array} & \begin{array}{c}\mathrm{RCG*} \\ (\boldsymbol{\mu C i} / \mathrm{mL})\end{array} \\ & 50 \mathrm{~m} * * & 2.48 \times 10^{-10} & 6.7 \times 10^{-8} \\ { }^{41} \mathrm{Ar} & 3 \mathrm{~km} & 9.40 \times 10^{-14} & 1.3 \times 10^{-8} \\ 85 \mathrm{Kr} & 600 \mathrm{~m} & 1.87 \times 10^{-13} & 1.0 \times 10^{-7}\end{array}$

\begin{tabular}{|c|}
\hline $\begin{array}{c}\text { Ratio of } \\
\text { Boundary } \\
\text { Concentration } \\
\text { to RCG } \\
\end{array}$ \\
\hline $3.7 \times 10^{-3}$ \\
\hline $7.2 \times 10^{-6}$ \\
\hline $1.9 \times 10^{-6}$ \\
\hline
\end{tabular}

\begin{tabular}{l}
$\begin{array}{l}\text { Dose } \\
\text { Rate } \\
(\text { mrem/yr) }\end{array}$ \\
\hline 0.63 \\
$1.2 \times 10^{-3}$ \\
$3.2 \times 10^{-4}$
\end{tabular}
Radiation
Protection
Guide (RPG)*
(mrem/yr)
170
170
170

Ratio of Site Boundary Dose Rate to RPG

$3.7 \times 10^{-3}$

$7.2 \times 10^{-6}$

$1.9 \times 10^{-6}$

*Standards for Radiation Protection, USERDA Manual Chapter 0524

$* *$ Though nearly equal amounts of tritium were emitted from Area V and Area I in 1979, the effect of Area $V$ tritium on boundary concentrations is negligible. 
Table 9

Annual Dose for Albuquerque Area

(in person-rem)

Nuclide

${ }^{3} \mathrm{H}$

$41 \mathrm{Ar}$

$85 \mathrm{Kr}$

$$
\begin{aligned}
& \frac{\text { Dose }}{1.3 \times 10^{-2}} \\
& 6 \times 10^{-2} \\
& 3.4 \times 10^{-3}
\end{aligned}
$$

Samples gathered at the radioactive dump showed no migration of uranium nor other alpha emitters. Tritium is the only beta emitter found outside a disposal pit. The highest tritium concentration found was $39 \%$ of the RCG for water.

The calculated site boundary concentrations for gaseous radionuclides are three or more orders of magnitude below applicable radiation guides. These concentrations cannot readily be measured. The gaseous radionuclides result in 0.076 person-rem over the $80 \mathrm{~km}$ radius Albuquerque area (Figure 1). The natural background found in the area results in 57,000 person-rem over the $80 \mathrm{~km}$ radius area (150 mrem/yr per person). The gaseous radionuclide impact is minute in comparison.

\section{Sandia's National Security Responsibilities}

National security is Sandia's prime concern, and thus Sandia is heavily involved with U. S. nuclear weapons. DOE's two other nuclear weapons laboratories, Los Alamos Scientific Laboratory (LASL) and Lawrence Livermore Laboratory (LLL) design the nuclear explosive packages used in nuclear weapons. Around these packages Sandia designs safing, arming, fuzing, and firing systems for nuclear weapon systems. Aerodynamic and structural designs are also made. The outcome of the work is a weapon system ready for other DOE contractors to manufacture and assemble. Sandia assures that each component is made to specifications.

The 1 imited test ban treaty has made research on hardening of U. S. nuclear weapons to enemy nuclear attack more difficult. Sandia has 
developed laboratory means to simulate nuclear weapons effects. Pulsed nuclear reactors and pulsed electron accelerators are principal tools for this research.

Sandia's Participation in Energy Research and Development

Sandia Laboratories participates in the national effort to expand our energy suurces. The Laboratories concentrate in areas where its experience, expertise and facilities permit a unique contribution.

\section{Nuclear Energy}

Nuclear reactor safety studies are conducted for the Nuclear Regulatory Commission. The Annular Core Research Reactor (ACRR) is a principal tool in these studies. Systems which permit the safe, secure transport and storage of special nuclear materials (1ike plutonium and uranium-235) are developed at Sandia. Sandia studies nuclear waste disposal techniques and sites.

\section{Radioactive Waste Products}

Sandia explores beneficial uses of radioactive waste products, such as sterilization of sewage sludge with intense $\mathrm{Cs}_{s}-137$ sources.

\section{Inertial Confinement Thermonuclear Fusion Research}

This research makes up one of Sandia's largest energy programs; its purpose is to determine if energetic subatomic particle beams or high powered lasers can cause miniature fusion explosions by striking (and thereby compressing and heating) pellets of deuterium and tritium (a radioactive material). These miniature explosions could be used to produce electric power.

\section{Solar Energy Research}

Facilities for this research include a 5 megawatt central receiver tower, a 12,000 square foot building heated, cooled, and powered by a solar collector field, and a vertical axis wind turbine. 
The laboratories are working to identify and develop technology that can reduce the time and cost required to use geothermal resources. Techniques are being developed for getting fuel directly out of oil shale and coal formations. Enhanced recovery of natural gas and oil from tight formations is another research area. Fossil energy research often requires fracturing a geological formation by mechanical means. The nature of a fractured zone is determined by injecting a pulse of $\mathrm{Kr}-85$ gas (a radioactive tracer) into an air stream flowing through the fracture zone. 


\section{References}

1. Environmental Impact Statement, Sandia Laboratories, Albuquerque, New Mexico, EIA/MA 77-1, ERDA, May 1977.

2. L. W. Brewer, Environmental Monitoring Report for Sandia Laboratories for 1973, SLA-74-0167, Sandia Laboratories, Albuquerque, NM, Apri1 1974.

3. W. L. Holley, Environmental Monitoring Report, Sandia Laboratories 1974, SAND 75-0257.

4. L. W. Brewer, Environmental Monitoring Report for Sandia Laboratories from 1964 through 1972 , SLA73-0339.

5. W. D. Burnett, D. J. Coleman, R. G. Eisbrock, and R. J. Everett, Radioactive Environmental Survey at Sandia Corporation, $\mathrm{SC}-4628(\mathrm{M})$.

6. W. L. Holley, T. N. Simmons, Environmental Monitoring Report, Sandia Laboratories 1975, SAND76-0209.

7. T. N. Simmons, Environmenta1 Monitoring Report, Sandia Laboratories 1976, SAND77-0616.

8. I. N. Simmons, Environmental Monitoring Report, Sandia Laboratories 1977, SAND 78-0620.

9. T. N. Simmons, Environmental Monitoring Report, Sandia Laboratories 1978, SAND 79-1033.

10. D. G. Jacobs, Sources of Tritium and its Behavior Upon Release to the Environment, USAEC/Division of Technical Information, 1968.

11. R. Bergman, U. Berstrom, and S. Evans, Environmental Transport and Long-Term Exposure for Tritium in the Environment, IAEA-SM-232/47, 1978 .

12. NCRP Report No. 62, Tritium in the Environment, March, 1979.

13. D. H. Slade, Editor, Meterology and Atomic Energy 1968, TID-24190, AEC, July 1968 .

14. Climatography of the United States No. 82-89, Summary of Hourly Observations, Albuquerque, New Mexico Municipal Airport 1951-1960, 1968.

15. O. Olson, M. H. Ha11, and H. J. Plagge, Wind Data for the Albuquerque Area, SC-M-70-144. Sandia Laboratories, Albuquerque, NM, May 1970.

16. A. Masuda, Distribution of Thorium, Uranium, and Potassium and Radioactive Heat Production as a Function of Depth of Earth, Rep. INSJ-65, Institute of Nuclear Studies, Japan (1964). 
U. S. Department of Energy (17)

Albuquerque Operations office, OSD

P. O. Box 5400

Albuquerque, NM 87185

Environmental Improvement Agency (5)

Health and Environment Department

P. O. Box 968, Crown Bldg.

Sunca re, NM 87503

Albuquerque City Environmental Services

400 Marquette Avenue, NW

Albuquerque, NM 87101

New Mexico State University

College of Agriculture and Home Economics,

Dept of Agronomy

Box 3Q/Las Cruces, NM 88003

Attn: P. J. Wierenga

Department of the Air Force

USAF Hospital Kirtland (MAC)

Hospital/SGPR

Kirtland AFB, New Mexico 87117

3151 B. J. To1man

3310 W. D. Burnett (5)

3311 D. R. Parker

3311 L. W. Brewer

3311 J. W. McKelvey

3312 G. E. Tucker, Jr.

3312 H. D. Abbott

3312 G. E. Kaye

3312 T. N. Simmons (30)

3312 R. B. Stump (2)

3313 A. L. Stanley

3313 G. E. Mi1lard

8266 E. A. Aas

3141 T. L. Werner (5)

3151 W. L. Garner (3) For DOE/TIC (Un1imited Release)

DOE/TIC (25)

(R. P. Campbe11, 3154-3) 